\title{
Political Regimes and Immigrant Party Preferences
}

Comparative Political Studies 2019, Vol. 52(5) 65I-686

(C) The Author(s) 2018

Article reuse guidelines: sagepub.com/journals-permissions DOI: $10.1177 / 0010414018797938$ journals.sagepub.com/home/cps

(S)AGE

\section{Aida Just ${ }^{1}$}

\begin{abstract}
This article examines how political regimes in migrants' origin countries influence their party identification in adopted homeland. I posit that immigrants are more likely to acquire partisanship in their host country if they came from a nonparty autocracy as opposed to a party-based autocracy or democracy. Moreover, among partisans, immigrants are less likely to identify with a left-wing party if they came from a communist regime. Finally, these effects are particularly pronounced among foreign-born individuals from highly authoritarian regimes. The analyses using Geddes, Wright, and Frantz Autocratic Regimes data along with individual-level data from the European Social Survey (ESS) 2002-2017 in 19 established democracies confirm these expectations. These findings have important implications for debates on immigrant political integration, party politics, and the prospects of electoral stability in contemporary democracies.
\end{abstract}

\section{Keywords}

immigrants, party identification, political regimes, autocracies, communism, political socialization

One feature of contemporary international migration is that people move from an increasingly diverse range of origin countries to a declining number

'Bilkent University, Ankara, Turkey

\section{Corresponding Author:}

Aida Just, Department of Political Science and Public Administration, Bilkent University,

Bilkent, Ankara 06800, Turkey.

Email: aidap@bilkent.edu.tr 
of destination countries (Czaika \& de Haas, 2015). Among these destinations, Europe has emerged as a primary magnet for new arrivals due to its economic prosperity, colonial ties, and the emergence of the European Union (EU) as a region of free trade and migration. In 2017, foreign-born individuals constituted on average $13.4 \%$ of total population in West European countries, ranging from $6.3 \%$ in Finland to $28.4 \%$ in Switzerland and 45.7\% in Luxembourg (Eurostat, 2018). ${ }^{1}$ While some of Europe's social diversity results from internal cross-border movements of EU citizens, most foreign-born individuals originate from outside the EU: In 2017, on average only $36.7 \%$ of all foreignborn individuals in West European countries were citizens of another EU country. ${ }^{2}$ Because many immigrants arrive from countries with little or no experience with democratic governance, questions have been raised about the consequences they may have for the functioning of democratic governance in their host societies.

These concerns are in part rooted in scholarship on political socialization that emphasizes the importance of early experiences in people's lives. It suggests that people acquire political orientations during formative years, and that, once acquired, these orientations tend to persist over time, as individuals avoid or reject messages that contradict views they already hold (Festinger, 1957; Sears \& Levy, 2003; Zaller, 1992). Consistent with this perspective, scholars found that socialization in undemocratic or repressive regimes indeed structures immigrants' attitudes toward democratic governance (Bilodeau, 2014; Bilodeau, McAllister, \& Kanji, 2010; Just, 2017; McAllister $\&$ Makkai, 1992) and influences the patterns of their political engagement in adopted homeland (Bilodeau, 2008; Just \& Anderson, 2012; White, 2017).

Existing research has not ventured far down this path, however. We still have limited knowledge of how experiences of political regimes in origin countries matter in shaping immigrant political orientations, such as allegiances to political parties. Understanding how immigrants develop party attachments is important not only because newcomer populations in Western Europe are increasing (Czaika \& de Haas, 2015) but also because, once acquired, partisanship is likely to persist and be transmitted to subsequent generations (Campbell, Converse, Miller, \& Stokes, 1960; Dalton, 2016; Franklin \& Jackson, 1983). Moreover, at the national level, even small numbers of immigrant voters can alter party fortunes in close elections (e.g., Dancygier \& Saunders, 2006, p. 963; Ramakrishnan, 2005, p. 2). ${ }^{3}$ And at the local level, geographic concentration of ethnic communities and the fact that many EU countries allow noncitizens to vote in local elections mean that newcomers can be transformed into a substantial political force (e.g., Money, 1997).

To advance research in this direction, this article examines how premigration experiences of political regimes matter in shaping party identification 
among foreign-born individuals in established democracies. I am particularly interested in whether exposure to a nonparty autocracy as opposed to a partybased autocracy or democracy influences partisanship acquisition, and whether experience of a communist regime has consequences for identification with a left-wing party among new arrivals. While political parties are crucial for the functioning of democratic governance (Aldrich, 1995), they are not exclusive to democratic regimes. Yet no previous study has systematically examined the consequences that having lived in a party-based autocracy may have for how immigrants relate to political parties in their adopted democratic homeland.

Building on scholarship on the varieties of autocracies (Geddes, 1999; Geddes et al., 2014), this article posits that immigrants who come from nonparty autocracies are more likely to develop party attachments in their host countries than arrivals from party-based regimes, including party autocracies and democracies. Moreover, among foreign-born individuals who have acquired partisanship, premigration experience of a communist regime contributes negatively to their identification with a left-wing party. Finally, I expect that these effects on partisanship acquisition and left-wing partisanship are likely to be more pronounced among foreign-born individuals who came from highly authoritarian regimes. I test these expectations using Geddes et al. (2014) Autocratic Regimes dataset along with individual-level data collected as part of the eight-round European Social Survey (ESS) between 2002 and 2017 in 19 established democracies.

The study contributes to existing research in several ways. First, whereas most studies on immigrant political attitudes and behavior focus on the consequences of newcomers' experiences in their host countries, this article more carefully considers premigration political socialization. In doing so, the analysis goes beyond classifying origin countries based on their democracy level and shows that accounting for different types of autocracies offers valuable insights into understanding the patterns of party identification among first-generation immigrants. The study also adds to the literature on the varieties of autocracies. Existing research in this area has made significant strides in explaining how different autocracies structure incentives for the ruling elites to generate various political and economic outcomes (e.g., Brownlee, 2007; Davenport, 2007; Geddes, 1999; Wright, 2008). This article shows that autocracy type also leaves a mark on how ordinary citizens relate to political parties and that this mark manifests itself in individual party allegiances even after these individuals relocate to another country. Finally, much of present research on immigrants' partisanship or political preferences is based on single- or few-country (or even city) cases and looks at a small number of selected immigrant groups (e.g., Bird, Saalfeld, \& Wüst, 2011, Ch. 3; Wüst, 
$2000,2004)$. This study breaks a new ground by systematically analyzing newcomers' party attachments in a wide range of countries with diverse immigrant populations.

\section{Party Identification and Its Origins Among Immigrants}

Since the behavioral revolution, political scientists have recognized party identification (or party attachment, partisanship) as a fundamental force in organizing people's political attitudes and behavior. Partisanship is typically understood as an individual's affective attachment to a political party that emerges from early socialization experiences and tends to endure over one's lifetime (Campbell et al., 1960, 1966; Franklin \& Jackson, 1983). Other scholars, particularly those working within the rational choice tradition, conceptualize partisanship as a cognitive cue, which represents a running tally of retrospective assessments of party performance (Fiorina, 1981).

Since foreign-born individuals have limited opportunities to be socialized into their host country's politics via family, traditional theories emphasizing parental socialization offer limited insights into the patterns of their partisanship. Recognizing this limitation, most studies of immigrant party preferences focus on immigrant experiences in their adopted homeland, while controlling for standard explanations of party choice. They find, for example, that immigrants prefer left-wing parties (e.g., Bergh \& Bjørklund, 2011; Bird et al., 2011, Chapter 3; Heath, Fisher, Sanders, \& Sobolewska, 2011; Sobolewska, 2005; Strijbis, 2014; Teney, Jacobs, Rea, \& Delwit, 2010), particularly among those who feel discriminated against in their host country (Sanders, Heath, Fisher, \& Sobolewska, 2014). Key explanations of this pattern focus on low socioeconomic status of most newcomers, but also leftwing parties' commitment to protect and promote minority interests, such as combating discrimination and xenophobia as well as nominating minority candidates on party lists at the time of elections.

Taken together, these studies suggest that rational calculations based on individual or group interests encourage immigrants to support left-wing parties in Western democracies. However, one puzzling finding is that some groups consistently prefer center-right parties. For example, in Germany, East European resettlers have favored strongly the Christian Democrats, while in Spain, a remarkable support for the Conservative Party has been found among Romanians (Bird et al., 2011, Ch. 3; Wüst, 2000, 2004). Moreover, in the United States, many Cuban Americans and Vietnamese Americans identify with the right-wing Republican Party while other Latinos and Asian Americans generally express loyalty to the Democratic Party (e.g., Alvarez \& Bedolla, 
2003; Cain, Kiewiet, \& Uhlaner, 1991; De la Garza, DeSipio, Garcia, Garcia, \& Falcon, 1992; Z. Hajnal \& Lee, 2006; Lien, Conway, \& Wong, 2004; Uhlaner \& Garcia, 2002). ${ }^{4}$ Similarly, East Europeans who emigrated to Switzerland before the collapse of Communism in their origin country have been found to identify with left-wing parties less than other immigrants (Strijbis, 2014). The same pattern applies to East European immigrants in Australia, where their party allegiances are less consistent with their socioeconomic status compared with other immigrants (McAllister \& Makkai, 1991, p. 205). In short, these studies suggest that while newcomers generally support left-wing parties, they are not homogeneous in their party loyalties. I argue that a comprehensive model of immigrant party loyalties should account for this heterogeneity and that this can be achieved by more carefully considering premigration experiences of foreign-born individuals.

\section{Political Regimes and Transferability of Political Orientations}

Scholars have long established that in processing political information and making political decisions, people often rely on information shortcuts, or heuristics (e.g., Lupia, 1994; Popkin, 1991). Because, compared with natives, immigrants have more limited exposure to their host country's politics, they may be particularly dependent on such heuristics. Consistent with this perspective, several studies show that foreign-born individuals transfer their political attitudes and behavioral habits as they migrate, especially when political and party systems of their origin and host countries are similar. For example, focusing on the U.S. immigrants in Australia, Finifter and Finifter (1989) discovered that foreign-born residents who identified with a party in their origin country were more likely to acquire partisanship also in their new homeland. Moreover, ideological predispositions obtained before migration played an important role in shaping newcomers' party allegiances in their settlement country. ${ }^{5}$

Yet studies interested in the consequences of premigration experiences on immigrant political attitudes and behavior usually focus on the level (or presence) of democracy in newcomers' country of origin (e.g., Bilodeau, 2008, 2014; Bilodeau et al., 2010; White, 2017). Although these studies have yielded some interesting insights, they may not fully capture all relevant differences across political regimes. Existing research suggests that autocracies differ from each other as much as they diverge from democracies (Geddes, 1999, p. 121). This is because they draw on different social groups to staff government offices, rely on various segments of society for support, and diverge considerably in their procedures for leadership selection and succession, policy decision-making, and 
handling society's demands (Geddes, 1999; Geddes et al., 2014). Distinguishing between single-party, military, and personalist regimes as the main types of autocracies, studies have shown that regime type has important consequences for regime durability (Brownlee, 2007; Dimitrov, 2013; Geddes, 1999), economic development and investment (Wright, 2008), human rights conditions (Davenport, 2007), state conflict (Lai \& Slater, 2006; Peceny, Beer, \& Sanchez-Terry, 2002), and the prospects of democratization and consolidation (Hadenius \& Teorell, 2007; Svolik, 2008). I suggest that regime type also plays an important role in shaping people's political orientations and that the distinction between nonparty and party-based political regimes may be particularly useful in explaining partisanship acquisition among foreign-born individuals in their adopted homeland.

\section{Nonparty Autocracies and Partisanship Acquisition Among Immigrants}

I posit that immigrants from nonparty autocracies are more likely to acquire party identification in their host country than newcomers from party-based autocracies or democracies. Existing research shows that foreign-born individuals from authoritarian regimes engage in their host country's politics more than immigrants from democratic countries when activated by high levels of political mobilization upon arrival (White, 2017), or when they acquire citizenship in their host country (Just \& Anderson, 2012). These findings are remarkable considering that foreign-born individuals from authoritarian regimes have more limited understanding of democratic governance and therefore should have more difficulty in navigating their host country's politics. Compared with newcomers from democracies, immigrants from autocracies thus appear to be more excited about exercising their newly found political rights and freedoms and are eager to join in the political process of their democratic host country, enabling them to overcome higher costs of political participation.

Building on this insight, immigrants from autocracies that prohibit or effectively prevent political parties from taking part in their origin country's governance can also be expected to have more appreciation for the presence of political parties in a political system and be more inclined to become partisans in their host country because they could not do so back at home. In contrast, for immigrants from democracies, political parties will not be a novel feature of a political regime: Although moving to another country means exposure to different parties, the fundamental workings of partybased democracy remain the same. Because arrivals from democracies are more likely to take political parties for granted, they will have fewer incentives to develop party attachments in their host country than immigrants from nonparty autocracies. 
At the same time, newcomers from nonparty autocracies are also more likely to become partisans relative to arrivals from party-based autocracies. Existing research suggests that individuals who lived in party autocracies have many reasons to dislike political parties. Studies show, for example, that, beside facilitating bargaining and cooperation among the ruling elites, an important function of political parties in party autocracies is to control and monitor ordinary citizens so that they remain loyal to the regime (Magaloni \& Kricheli, 2010). To collect information about citizen loyalty, the ruling party usually develops an extensive organizational network with branches and cells extending to various social groups-youth, workers, teachers, peasants, etc.- - while at the same time prohibiting the existence of other parties or associations (Magaloni \& Kricheli, 2010, p. 129). This extensive network enables the party to continuously observe citizens and sanction them using punishment and material inducements via the patronage system. Consequently, people become "trapped" into supporting the political system because they have few other alternatives to ensure their livelihood and career advancement. ${ }^{6}$ Although these control mechanisms may exist in other types of autocracies as well, unlike party-based autocracies, they are not implemented by the institution of a political party.

Because party autocracies rely heavily on cooptation of citizens into the political system, they are often considered to be more inclusive than other autocracies (e.g., Davenport, 2007; Geddes, 1999). However, inclusiveness does not mean that citizens join parties and their political activities voluntarily, or that they enjoy more opportunities for meaningful and effective participation (Geddes, 1995, p. 252). Research from the Soviet Union reveals that most people became party members and displayed political activism out of conformity rather than individual initiative (DiFranceisco \& Gitelman, 1984; Kuran, 1991). Moreover, their political activism was ritualistic, which means that individuals were required to attend party meetings and take part in political debates, but few expected to have any tangible impact on party policies (DiFranceisco \& Gitelman, 1984; Unger, 1981, p. 111). ${ }^{7}$

I argue that exposure to such political environment leaves a mark on the attitudes and behavior of ordinary citizens. Existing research shows that emigrants from the Soviet Union express high levels of political apathy, cynicism, and mistrust and that this mistrust is particularly pronounced with respect to political parties (DiFranceisco \& Gitelman, 1984; Holmes, 1997, p. 16; Unger, 1981). Survey evidence from East Central Europe in the early 1990s similarly revealed that, after the dismantlement of their party-based autocracies, political parties were the least trusted political institution: Only 5\% of citizens expressed trust toward political parties, while the rest were either skeptical (50\%) or distrustful (45\%) (Rose, Mishler, \& Haerpfer, 1998, pp. 154-155). 
Because foreign-born individuals have more limited exposure to their host country's politics, premigration experiences are likely to provide a convenient cue when orienting themselves in a new political environment. For immigrants from party-based autocracies, the party that they know best is the ruling party in their origin country, and their views of parties as political institutions are likely to be tainted by experiences with autocratic party politics back at home. They are more likely to be aware that party as an institution is not exclusive to democracies and that it can be successfully employed to govern and prolong an authoritarian regime. Moreover, compulsory and ritualistic political engagement as well as the far-reaching control of the ruling party can generate a sense of futility of political activism and distrust in parties.

Hence, whereas immigrants from nonparty autocracies can be expected to welcome opportunities to identify with a political party because they could not do so back at home, arrivals from party-based autocracies will instead appreciate a newly found freedom not to participate in politics, and therefore remain unaligned with political parties. This perspective is consistent with previous research, which shows low levels of partisanship in East Central Europe after the collapse of party-based autocracies in the early 1990s - a pattern usually explained by people's desire to exercise their freedom to stay away from party politics (Rose \& Haerpfer, 1993, p. 17; Geddes, 1995). Similarly, studies on immigrants in the United States reveal low levels of partisanship among Chinese and Vietnamese Americans (Lien et al., 2004) the two groups whose origin countries have been governed by party-based autocracies for a long time. Hence, my first hypothesis:

Hypothesis 1: Foreign-born individuals from nonparty autocracies are more likely to acquire party identification in their host country than immigrants from party-based autocracies or democracies.

\section{Communist Regimes and Identification With Left- Wing Parties}

Besides understanding the effect of being from a nonparty autocracy on partisanship acquisition, I am also interested in how the nature of political regimes in migrants' origin country influences the ideological orientation of this newly acquired partisanship. The specific question I seek to address is whether premigration exposure to a communist regime-that is, an autocracy with a clearly defined far-left ideology-reduces the chances of identification with a left-wing party among foreign-born individuals in their democratic host country. 
Political ideology defines the goals for the regime, identifies the "chosen" social group for which the rulers speak, and specifies the struggle against its enemies - such as capitalists, imperialists, and traditionalists in the case of communism. As such, ideology provides guidance for the actions of the leaders, legitimizes the political order, and facilitates political mobilization of ordinary citizens. Autocracies vary with respect to political ideology of their leaders and the extent to which rulers rely on ideology in governing their countries (e.g., Brooker, 2009, pp. 171-173). Existing research suggests that ideology plays a major role in party-based autocracies (Huntington \& Moore, 1970) and that most party-based autocracies have been communist (e.g., Brooker, 2009, Ch. 4; Davenport, 2007; Peceny et al., 2002). At the same time, communism and party autocracies do not overlap completely. For example, some communist regimes, such as Cuba and North Korea, fall into the category of mixed regimes, combining features of both party and personalist autocracies. Other countries, such as Mexico or Tanzania, experienced many years of single-party autocracy but never became communist regimes. ${ }^{8}$

I posit that arrivals from communist regimes should be less likely to become partisans of left-wing parties in their host country because they react against the far-left ideology of their origin country's autocracy. As noted above, the ruling elites in party-based autocracies seek to control citizens so that they remain loyal to the regime by developing a network that allows the party in power to monitor citizens, reward them, and sanction them via the party's patronage system. Centralized command economy-one of the defining features of communist regimes (Walder, 1994) — makes this process especially effective, as the ruling party has a complete monopoly over all valuable resources and decisions regarding production, investment, and wages in the country's economy. This not only provides the ranking party members with extensive privileges but also enables communist regimes to have a particularly high degree of control over citizens' income and career opportunities (Walder, 1994, p. 299). Moreover, a suppression of private production, trade, and retail markets often results in consumer goods shortages, further reinforcing citizen dependence upon the ruling party for the satisfaction of their basic needs (Walder, 1994, pp. 300-301).

Enhanced party's control, economic inefficiencies, and diminished opportunities for ordinary citizens to ensure livelihood outside the party's patronage system can generate a negative reaction in the mass publics toward the regime. Existing research shows that public hostility toward communism has been widespread in many countries that sought to implement it (e.g., Darden \& Grzymala-Busse, 2006; Kuran, 1991, p. 32). ${ }^{9}$ And because reliance on centralized command economy gives communist regimes a distinct far-left ideological identity, one way in which this negative reaction may manifest itself 
is the adoption of right-wing political views. Existing studies show that individuals retain these views even after relocating to another country. For example, research on immigrants in the United States reveals strong anticommunist feelings among Chinese (Takaki, 1989), Cuban (Girard, Grenier, \& Gladwin, 2012), as well as Vietnamese and Soviet immigrants (Gold, 1986). In Western Europe, anticommunist sentiment among those East Europeans who emigrated before the collapse of Communism in their origin country has demonstrated itself in a negative identification with Socialist parties (Strijbis, 2014). Taken together, existing scholarship suggests that there is indeed a backlash against the ideological nature of communist autocracies among individuals who lived in these regimes ${ }^{10}$ and that this backlash displays itself in the way foreign-born individuals relate to the ideological nature of political parties in their host country. This leads to my next hypothesis:

Hypothesis 2: Foreign-born individuals from communist regimes are less likely to develop an identification with a left-wing party in their host country than immigrants from noncommunist regimes.

Finally, I examine whether the effects of nonparty autocracy and communism interact with the level of authoritarianism in migrant's origin country in shaping the patterns of party identification. Specifically, I expect that the positive effect of nonparty autocracy on partisanship acquisition and the negative effect of communism on left-wing partisanship are enhanced by the degree of authoritarianism in origin country. This means that individuals who arrived from a nonparty autocracy that was highly authoritarian should be especially excited about their newly found opportunities to take part in their host country's politics and therefore particularly inclined to develop party attachments. Conversely, those whose origin country's nonparty autocracy enabled them to enjoy at least some political rights and freedoms or offered limited opportunities for political contestation should have fewer incentives to become partisans in their new homeland. Similarly, a negative effect of communism on left-wing partisanship should be less pronounced if a foreignborn individual experienced communism in a context of harsh authoritarianism as opposed to mild authoritarianism. In short, being from a less authoritarian regime should weaken the effects that exposure to a nonparty autocracy or communism has on partisanship in one's host country. In contrast, coming from a highly authoritarian regime should strengthen these effects. Hence, my final two hypotheses are as follows:

Hypothesis 3: Foreign-born individuals from nonparty autocracies are particularly likely to acquire party identification if they came from a highly authoritarian regime. 
Hypothesis 4: Foreign-born individuals from communist regimes are particularly unlikely to develop an identification with a left-wing party if they came from a highly authoritarian regime.

\section{Data and Measures}

I test my hypotheses using individual-level data collected as part of the eightwave ESS 2002-2017. This project is well known for its high standards in crossnational survey design and data collection (Kittilson, 2009). Strict random sampling of individuals aged 15 years or older regardless of citizenship, nationality, legal status, and language was used to guarantee nationally representative samples. ${ }^{11}$ Moreover, the data have been shown to have samples of foreign-born respondents that closely match their host country's official statistics regarding immigrant origins (for details, see Just \& Anderson, 2012). In addition, the ESS project is the only set of cross-national surveys that ask questions related to respondents' foreign-born status, citizenship, origin country, and duration of stay in the host country, alongside standard questions about partisanship. Nineteen advanced industrialized democracies from Western Europe with considerable immigrant populations were included in the study: Austria, Belgium, Cyprus, Denmark, Finland, France, Great Britain, Germany, Greece, Iceland, Ireland, Italy, Luxembourg, the Netherlands, Norway, Portugal, Spain, Sweden, and Switzerland.

\section{Dependent Variable}

To measure party identification, I relied on two survey questions: "Is there a particular political party you feel closer to than all the other parties?" If so, "Which one?" These survey questions have been widely used in crossnational research because they provide a clear opportunity for respondents to record a "non-identity" and have been shown to provide a valid indicator of party identification across countries with different party systems (Blais, Gidengil, Nadeau, \& Nevitte, 2001; Budge, Crewe, \& Farlie, 1976; Holmberg, 1994; Sanders, Burton, \& Kneeshaw, 2002). I first created a dichotomous measure, where 1 indicates a positive response to the first question and 0 , a negative response. Looking at the data reveals that $41 \%$ of foreign-born immigrants reported feeling close to a party in their host country (compared with $56 \%$ among natives). ${ }^{12}$

My second dependent variable-left-wing party identification-is designed to capture the ideological orientation of a party that respondent identifies with. To create this variable, I matched individual responses to survey questions about party identification with information on ideological orientations of political parties from the Chapel Hill Expert Survey data (Bakker 
et al., 2015). Specifically, parties were coded as left-wing if they scored less than five on a scale from 0 to 10 of the left-right continuum (where 0 indicates radical left and 10, radical right) in the Chapel Hill data. ${ }^{13}$ The resulting variable is dichotomous, where 1 indicates that respondent identifies with a left-wing party and 0 , any other party (detailed information on left-wing parties in each country is available in the Online Appendix). The data show that $55 \%$ foreign-born individuals who are partisans identify with a left-wing party (compared with $43 \%$ among natives).

\section{Key Independent Variables}

To identify foreign-born respondents, I relied on the ESS question: "Were you born in this country?" Answers were coded dichotomously, with 1 indicating that an individual is foreign-born and 0 , native-born. In addition, questions "Was your father born in this country?" and "Was your mother born in this country?" were used to detect respondents who are foreign-born but whose both parents are native-born. These individuals $(10.25 \%$ of all foreign-born respondents) were excluded from the sample to ensure that only "true" immigrants are used in the analyses described below. Pooling the ESS data across all countries and eight survey rounds generated a sample of 20,767 foreign-born respondents $(8.89 \%$ of all surveyed individuals in the ESS data). Moreover, excluding respondents who were below the age of 18 years at the time of the survey - the legal age for political participation in most countries - resulted in a sample of 20,316 of foreign-born individuals.

I used several measures to capture the nature of political regime in migrants' origin country: regime type, polity score, and the presence of a communist leader. To incorporate these indicators in the ESS data, I employed the following survey items: "Were you born in this country?" If a respondent said "no," two follow-up questions were employed: "In which country were you born?" and "How long ago did you first come to live in this country?" Individual responses to these questions were then matched with information about political regimes in one's origin country at the time of migration.

To measure regime type, I relied on the Autocratic Regimes dataset by Geddes et al. (2014) that classifies autocracies into monarchies, personalist, military, and party autocracies, as well as several mixed-type autocraciesparty-personalist, party-military, military-personalist, and party-personalist-military regimes. Because the purpose of my study is to assess the impact of nonparty autocracies on partisanship acquisition among foreign-born individuals, I grouped monarchies, personalist, military, and military-personalist regimes into a dichotomous variable of nonparty autocracies ${ }^{14}$ In contrast, party autocracies contain single-party autocracies as well as those mixed 


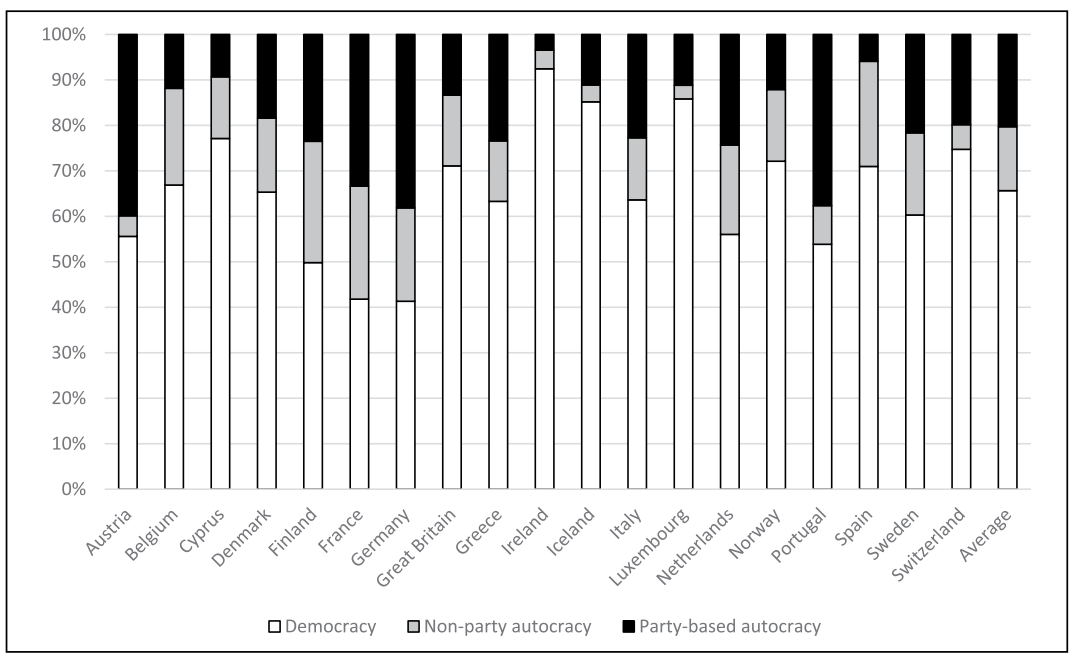

Figure I. Percentage of foreign-born individuals by their origin country's political regime at the time of migration in 19 established democracies, 2002-2017.

autocracies that include political parties in their governance, that is, partypersonalist, party-military, and party-personalist-military regimes. ${ }^{15}$ To isolate the effects of different types of autocracies, all models also include a dummy variable for democracies, and some models additionally control for mixed autocracies to assess the effects of pure-type nonparty autocracies as opposed to pure party autocracies.

Figure 1 shows the shares of foreign-born individuals from different political regimes: It reveals that $66 \%$ of first-generation immigrants in Western Europe came from a country that was classified as a democracy at the time of arrival. Among immigrants from autocracies, a majority of $59.1 \%$ arrived from party-based autocracies (or $20.3 \%$ of all foreign-born arrivals), and $40.9 \%$ from nonparty autocracies (or $14.04 \%$ of all foreign-born arrivals). At the same time, there is some variation in the shares of immigrants from nonparty and party-based autocracies across host countries. For example, nations that are geographically closer to East Central Europe - such as Germany and Austria - have larger shares of foreign-born individuals from party autocracies (38\%- $40 \%$ of all foreign-born in these countries) than other West European countries. ${ }^{16}$ In contrast, France, Spain, Belgium, and Finland host the largest shares of immigrants from nonparty autocracies $(21 \%-26 \%$ of all arrivals in these countries), while Luxembourg, Iceland, and Ireland host the smallest percentages of individuals from such regimes (3\%-4\%). ${ }^{17}$ 
To test whether exposure to communism in origin country reduces the chances of left-wing partisanship acquisition among foreign-born individuals, I include a dummy variable coded 1 if there was a communist leader in an immigrant's origin country (0 otherwise). This measure was taken from the Democracy and Dictatorship Revisited dataset developed by Cheibub, Gandhi, and Vreeland (2010). ${ }^{18}$ Looking at the ESS data reveals that $37 \%$ of foreign-born individuals who arrived from autocracies had a communist leader in their origin country. However, as previously noted, not all partybased autocracies have been communist: the ESS data reveal that $61 \%$ of arrivals from party-based autocracies (and 74\% from pure-type party autocracies) had a communist leader. Many of these individuals came from countries such as the former Soviet Union and Yugoslavia during the Cold War, but also include arrivals from more distant shores, such as China and Vietnam. The less numerous noncommunist party autocracies include Angola (19751990), Cape Verde (1975-1989), Ivory Coast (1960-1989), and Mozambique (1975-1990). ${ }^{19}$

Finally, to test whether the levels of authoritarianism magnify the effects of nonparty autocracies and communism on partisanship acquisition and leftwing partisanship, I employ polity scores - a widely used measure of political regimes from the Polity IV project dataset (Jaggers \& Gurr, 1995; Marshall, Gurr, \& Jaggers, 2017). The dataset has many advantages: It provides comparative data for virtually all countries in the world on an annual basis from either 1800 or the year of independence up to 2016, currently the latest year available. It also relies on a comprehensive definition of democracy and autocracy: Its polity indicator rests on a sum of five components that reflect the competitiveness and the openness of executive recruitment, constraints on the chief executive, and the regulation and competitiveness of political participation. The variable ranges from -10 to +10 , with lower values indicating more authoritarian regimes and higher values indicating more democratic political systems. (For more information on variable coding, please see the Online Appendix.)

\section{Control Variables}

To isolate the effects of political regimes from the impact of other variables, my analyses include a set of variables found to be important determinants of partisanship in previous research. People generally engage in politics more if they have the necessary resources and motivations to do so. The most prominent measure for resources has been socioeconomic status (Verba, Schlozman, \& Brady, 1995), and substantial research shows that education and socioeconomic status (measured by income or class) have positive effects on political 
engagement across a variety of countries (Almond \& Verba, 1963; Jennings \& van Deth, 1989; Verba, Nie, \& Kim, 1971). Because there is evidence that these findings extend to immigrants when explaining their partisanship acquisition (Wong, 2000, p. 137; Wong, Ramakrishnan, Lee, \& Junn, 2011), my analyses account for respondent's socioeconomic status in a form of income, education, manual skills, and employment status.

Controlling for socioeconomic status is important also in the models of left-wing party identification because left-wing parties have traditionally promoted interests of the poor (e.g., Cain et al., 1991; Zingher \& Thomas, 2012). Besides socioeconomic status, I include two indicators of respondents' ideological orientations available in the ESS data that are designed to capture people's attitudes toward economic and social issues traditionally associated with the left-right ideological continuum. These variables are support for income redistribution and attitudes toward gays and lesbians.

Political engagement increases with age, although it declines slightly among the particularly old (Niemi, Powell, Stanley, \& Evans, 1985; Verba \& Nie, 1972). Among foreign-born immigrants, age contributes positively to partisanship acquisition even when accounting for duration of stay in a host country (White, Nevitte, Blais, Gidengil, \& Fournier, 2008). Gender is another important control because women have usually been less politically active than men due to traditional gender stereotypes and more limited resources available to them (e.g., Hansen, 1997; Jennings, 1983).

My models also account for individual social connectedness, which is expected to contribute positively to political engagement (Cain et al., 1991; Wolfinger \& Rosenstone, 1980). This means that married, union members, or those who meet more frequently with others are more likely to acquire partisanship than those who lead more socially isolated lives. Attendance of religious services, too, may provide a boost to partisanship acquisition, although its effect on the choice of parties is more difficult to predict (e.g., Bishin \& Klofstad, 2012; Calhoun-Brown, 1996; Ndukwe, 2015; Verba, Schlozman, Brady, \& Nie, 1993). ${ }^{20}$ In addition, I control for whether respondent is Christian, Jewish, Muslim, or belongs to some other non-Christian group. While for Christians a suitable political choice may be a socially conservative right-wing party, the growing divide between Islam and Christianity in contemporary democracies implies that Muslims may be more comfortable developing links with secular political parties than with parties that are explicitly Christian (Wüst, 2004).

Another variable central to understanding immigrant political behavior is discrimination, expected to contribute positively to political activism and attachment to a party that is committed to address it (Cain et al., 1991; Chong \& Kim, 2006; Uhlaner, 1991; Sanders et al., 2014). ${ }^{21}$ Social grievances are 
additionally captured by whether a respondent is a crime victim - an experience that has been found to enhance political participation (Bateson, 2012). Moreover, because my study focuses on foreign-born immigrants, I also control for citizenship status, duration of stay in a host country, and linguistic skills - all of which are expected to stimulate partisanship acquisition by providing enhanced opportunities, motivations, and resources for political engagement (Cain et al., 1991; White et al., 2008; Wong, 2000; Wong et al., 2011). GDP per capita in origin country was included to ensure that the observed effects of the political regime variables are not driven by the level of economic development in migrant's origin country. Finally, at the macrolevel, existing research suggests controlling for host country's opinion climate toward immigrants, as immigrants are more likely to engage politically in more hospitable social environments (e.g., Just \& Anderson, 2014).

\section{Analysis and Results}

My analyses rely on public opinion data collected at the levels of individuals and countries. This means that the data have a multilevel structure, where one unit of analysis - the individual — is nested within another unit - the country. Such data structure may lead to statistical problems, such as clustering, nonconstant variance, and incorrect standard errors (cf. Snijders \& Bosker, 1999; Steenbergen \& Jones, 2002). Furthermore, the estimates of a variance-components model (analysis of variance [ANOVA]) reveal a statistically significant variation in the levels of my dependent variables at both micro- and macro-level, suggesting that a hierarchical model is preferred to an ordinary regression. Given the dichotomous nature of my dependent variables, the analyses reported below rely on multilevel (random-intercept) logistic regressions. Cell values in each table represent log odds with their standard errors in parentheses, while odds ratios are shown in italics.

Previous research on immigrant party identification suggests that willingness to think in partisan terms is often a step that is separate from, or prior to, identification with a particular party (Hajnal \& Lee, 2011; Wong et al., 2011, p. 130). Following this research, I analyze party identification among foreign-born immigrants as a two-step process: (a) partisanship acquisition and (b) identification with a left-wing party among those who have acquired partisanship.

Table 1 reports the results for my first dependent variable — partisanship acquisition - among foreign-born individuals. The baseline model results in the first column reveal no statistically significant difference between foreign-born individuals who came from democracies as opposed to those who arrived from nondemocratic regimes. Hence, contrary to a common 


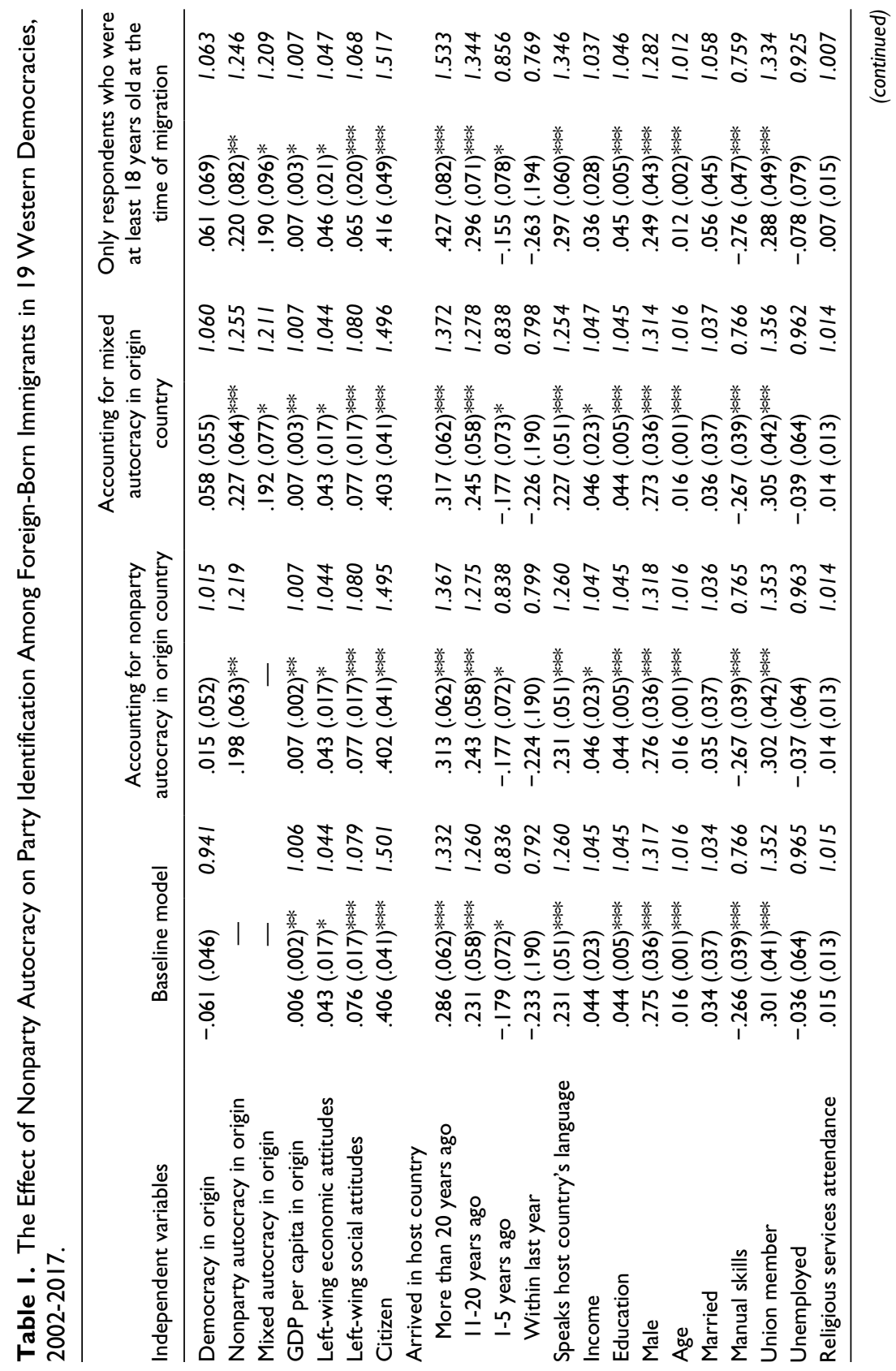




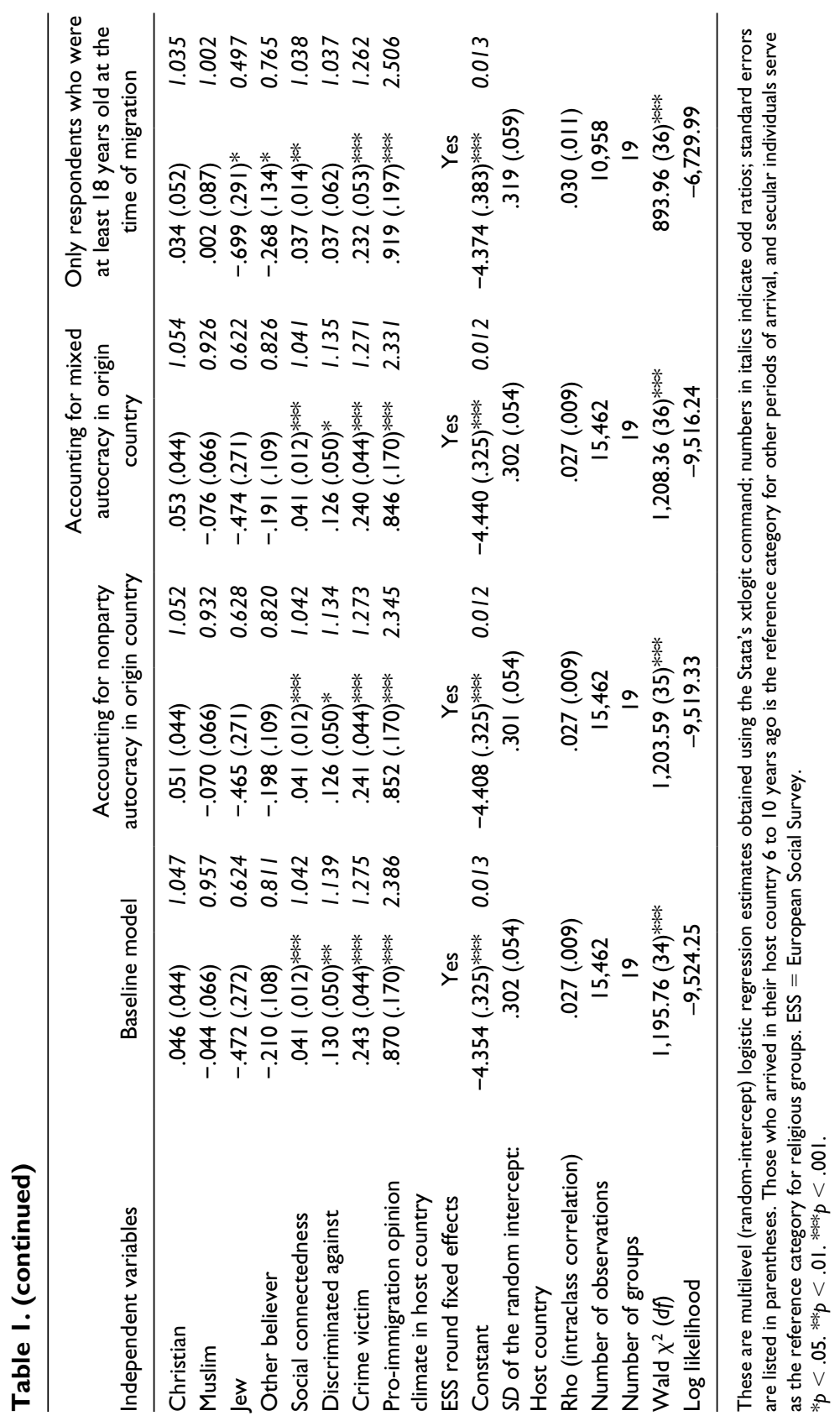


assumption, newcomers from democracies are not more likely to adopt party identification than immigrants from autocracies, even though the former have more familiarity with democratic governance than the latter. Replacing the dichotomous measure of democracy with polity scores in origin country (not shown) does not alter this finding: The polity coefficient fails to achieve the conventional levels of statistical significance.

Column 2 in Table 1 reports the results when I additionally include a variable measuring whether a foreign-born respondent arrived from a nonparty autocracy. Note that, as democracy in origin country is already controlled for, the reference category in this model is party-based autocracies. Consistent with my expectations, being from a nonparty autocracy is positively related to partisanship acquisition in one's host country. This means that, compared to arrivals from party-based autocracies, foreign-born individuals from nonparty autocracies are more likely to become partisans in their new homeland. At the same time, the coefficient for democracy remains statistically insignificant, indicating that arrivals from democratic countries are statistically indistinguishable from immigrants from party-based autocracies..$^{22}$ Column 3 in Table 1 reports the results of my estimations when I additionally control for mixed autocracies. Doing so enables me to assess the impact of pure-type nonparty autocracies relative to pure-type party-based autocracies. The results reveal that the coefficient of being from a nonparty autocracy increases in magnitude both in substantive and statistical terms. ${ }^{23}$ Hence, I still find that foreign-born individuals from nonparty autocracies are considerably more likely to become partisans relative to immigrants from party-based autocracies, but this relationship is even stronger when we compare pure-type autocracies.

Finally, column 4 in Table 1 reports the results when we focus exclusively on foreign-born individuals who migrated after they reached adulthood in their origin country - that is, those who were at least 18 years old at the time of arrival in their host country. The rationale for excluding younger respondents at the time of migration is that they had more limited opportunities to be socialized in their origin country's political regime than those who migrated at a later age. ${ }^{24}$ These estimations reveal that the results with respect to my key variable of interest remains essentially unchanged: I still find that foreign-born individuals from nonparty autocracies are more likely to become partisans than those who came from party-based autocracies, and this difference remains statistically significant.

These results are confirmed when I reestimate the model using pairwise comparisons of political regimes (see the Online Appendix). Specifically, when I exclude foreign-born respondents from democracies, I find that foreign-born respondents from nonparty autocracies are more likely to acquire partisanship than those who arrived from other types of autocracies. Similarly, 
excluding respondents from party-based autocracies generates a positive and statistically significant coefficient for being from a nonparty autocracy. This means that newcomers from nonparty autocracies are also more likely to acquire partisanship than immigrants from democracies. Interestingly, the coefficient becomes even stronger in substantive terms in this model, in line with my theoretical expectations that foreign-born individuals from nonparty autocracies are eager to join in the political process of their democratic host country by acquiring party identification because they did not have these opportunities in their origin country. In contrast, dropping respondents from nonparty autocracies from the sample reveals that foreign-born individuals from party-based autocracies are statistically indistinguishable from immigrants from democratic regimes with respect to their partisanship acquisition. Taken together, the results confirm that grouping autocracies into a single category masks important differences that are relevant for understanding partisanship acquisition among foreign-born individuals, and that immigrants from nonparty autocracies are significantly more likely to acquire party identification than newcomers from party-based political regimes.

Table 2 focuses exclusively on partisans among foreign-born individuals to assess the extent to which exposure to communist leadership before migration influences the nature of their party identification. ${ }^{25}$ As before, the baseline model estimations reveal that merely distinguishing between democracies and nondemocracies in origin country provides no insight into the patterns of partisanship among foreign-born individuals (column 1 in Table 2). ${ }^{26}$ However, accounting for whether there was a communist leader in one's origin country at the time of migration shows that those who originated from these regimes are significantly less likely to identify with a left-wing party in their host country than arrivals from noncommunist countries (column 2 in Table 2). Moreover, excluding foreign-born respondents who migrated to their host country before the age of 18 years shows that the negative coefficient for communism becomes even larger in substantive terms while retaining its high statistical significance (column 3 in Table 2).

As a next step, I test whether my key variables of interest-nonparty autocracy and communism - interact with authoritarianism level in origin country in shaping the patterns of partisanship among foreign-born individuals. To assess the substantive impact of this interaction, Figure 2 shows how the marginal effect of being from a nonparty autocracy on the probability of partisanship acquisition changes as we move from the lowest to the highest value of the polity measure, that is, from the most authoritarian to the most democratic political regime (dotted lines indicate $95 \%$ confidence intervals). In line with my expectations, the marginal effect of being from a nonparty autocracy is positive and becomes statistically indistinguishable from zero 
Table 2. The Effect of Communism on Left-Wing Party Identification Among Foreign-Born Immigrants (Partisans Only) in 19 Western Democracies, 2002-2017.

\begin{tabular}{|c|c|c|c|c|c|c|}
\hline \multirow{2}{*}{$\begin{array}{l}\text { Independent variables } \\
\text { Democracy in origin }\end{array}$} & \multicolumn{2}{|c|}{ Baseline model } & \multicolumn{2}{|c|}{$\begin{array}{l}\text { Accounting for } \\
\text { communism in origin } \\
\text { country }\end{array}$} & \multicolumn{2}{|c|}{$\begin{array}{c}\text { Only respondents } \\
\text { who were at least } 18 \\
\text { years old at the time of } \\
\text { migration }\end{array}$} \\
\hline & $.096(.074)$ & 1.101 & $-.055(.083)$ & 0.946 & $-.124(.100)$ & 0.883 \\
\hline Communist leader in origin & - & & $-.373(.094)^{* * * *}$ & 0.689 & $-.390(.117)^{* * * * *}$ & 0.677 \\
\hline GDP per capita in origin & $-.024(.004)^{* * * *}$ & 0.977 & $-.023(.004)^{* * * *}$ & 0.978 & $-.023(.005)^{* * * *}$ & 0.977 \\
\hline Left-wing economic attitudes & $.338(.026)^{* * * * *}$ & 1.402 & $.337(.026)^{* * * *}$ & 1.401 & $.338(.03 \mathrm{I})^{* * * * *}$ & 1.402 \\
\hline Left-wing social attitudes & $.118(.026)^{* * * *}$ & 1.125 & $.118(.026)^{* * * *}$ & 1.125 & $.131(.030)^{* * * *}$ & 1.140 \\
\hline Citizen & $-.151(.062)^{*}$ & 0.860 & $-.150(.062)^{*}$ & 0.860 & $-.175(.074)^{*}$ & 0.839 \\
\hline $\begin{array}{l}\text { Arrived in host country: } \\
\text { More than } 20 \text { years ago }\end{array}$ & $-.088(.100)$ & 0.916 & $-.044(.101)$ & 0.957 & $.017(.127)$ & 1.017 \\
\hline II-20 years ago & $-.013(.097)$ & 0.987 & $.024(.097)$ & 1.024 & $.002(.115)$ & 1.002 \\
\hline I-5 years ago & $.006(.127)$ & 1.006 & $.003(.127)$ & 1.003 & $-.043(.136)$ & 0.958 \\
\hline Within last year & $-.367(.332)$ & 0.693 & $-.356(.331)$ & 0.700 & $-.446(.340)$ & 0.640 \\
\hline $\begin{array}{l}\text { Speaks host country's } \\
\text { language }\end{array}$ & $-.184(.083)^{*}$ & 0.832 & $-.195(.083)^{*}$ & 0.823 & $-.190(.097)$ & 0.827 \\
\hline Income & $-.141(.035)^{* * * *}$ & 0.868 & $-.138(.035)^{* * * *}$ & $0.87 I$ & $-.133(.042)^{* * * * *}$ & 0.875 \\
\hline Education & $-.001(.007)$ & 0.999 & $-.002(.007)$ & 0.998 & $-.007(.008)$ & 0.993 \\
\hline Male & $-.113(.054)^{*}$ & 0.893 & $-.117(.054)^{*}$ & 0.890 & $-.094(.063)$ & 0.910 \\
\hline Age & $-.009(.002)^{* * * *}$ & 0.991 & $-.009(.002)^{* * * *}$ & 0.991 & $-.013(.003)^{* * * *}$ & 0.987 \\
\hline Married & $-.150(.056)^{* *}$ & 0.860 & $-.150(.056)^{* *}$ & 0.861 & $-.167(.067)^{*}$ & 0.846 \\
\hline Manual skills & $.096(.060)$ & 1.101 & $.096(.060)$ & 1.101 & $.106(.071)$ & 1.112 \\
\hline Union member & $.363(.061)^{* * *}$ & 1.438 & $.369(.061)^{* * * *}$ & 1.446 & $.425(.071)^{* * * *}$ & 1.529 \\
\hline Unemployed & $.090(.106)$ & 1.094 & $.088(.106)$ & 1.092 & $.082(.129)$ & 1.086 \\
\hline Religious services attendance & $-.064(.020)^{* * * *}$ & 0.938 & $-.066(.020)^{* * * *}$ & 0.936 & $-.084(.023)^{* * * * *}$ & 0.920 \\
\hline Christian & $-.412(.065)^{* * * *}$ & 0.662 & $-.402(.065)^{* * * *}$ & 0.669 & $-.47 \mid(.076)^{* * * * *}$ & 0.624 \\
\hline Muslim & $.526(.111)^{* * * *}$ & 1.692 & $.472(.112)^{* * * *}$ & 1.604 & $.439(.143)^{* * *}$ & 1.551 \\
\hline Jew & $-1.112(.421)^{* *}$ & 0.329 & $-1.125(.422)^{* * *}$ & 0.325 & $-1.1111(.480)^{*}$ & 0.329 \\
\hline Other believer & $.261(.176)$ & 1.299 & $.259(.176)$ & 1.296 & $.304(.220)$ & 1.355 \\
\hline Social connectedness & $.058(.018)^{* *}$ & 1.060 & $.057(.018)^{* * *}$ & 1.059 & $.065(.021)^{* *}$ & 1.067 \\
\hline Discriminated against & $.141(.077)$ & 1.151 & $.134(.077)$ & 1.144 & $.082(.095)$ & 1.085 \\
\hline Crime victim & $-.041(.063)$ & 0.960 & $-.048(.063)$ & 0.953 & $-.088(.076)$ & 0.916 \\
\hline $\begin{array}{l}\text { Pro-immigration opinion } \\
\text { climate in host country }\end{array}$ & $-.363(.275)$ & 0.696 & $-.379(.279)$ & 0.684 & $-.295(.282)$ & 0.744 \\
\hline ESS round fixed effects & \multicolumn{2}{|l|}{ Yes } & \multicolumn{2}{|l|}{ Yes } & \multicolumn{2}{|l|}{ Yes } \\
\hline Constant & $.609(.517)$ & 1.839 & $.777(.527)$ & 2.176 & $1.049(.554)$ & 2.855 \\
\hline $\begin{array}{l}\text { SD of the random intercept: } \\
\text { Host country }\end{array}$ & \multicolumn{2}{|c|}{$.515(.139)$} & \multicolumn{2}{|c|}{$.54 I(.14 I)$} & \multicolumn{2}{|c|}{$.410(.130)$} \\
\hline Rho (intraclass correlation) & \multicolumn{2}{|c|}{$.075(.037)$} & \multicolumn{2}{|l|}{$.082(.039)$} & \multicolumn{2}{|c|}{$.049(.029)$} \\
\hline Number of observations & \multicolumn{2}{|c|}{6,672} & \multicolumn{2}{|l|}{6,672} & \multicolumn{2}{|l|}{4,882} \\
\hline Number of groups & \multicolumn{2}{|l|}{19} & \multicolumn{2}{|l|}{19} & \multicolumn{2}{|l|}{19} \\
\hline Wald $\chi^{2}(d f)$ & \multicolumn{2}{|c|}{$607.23(34)^{* * * *}$} & \multicolumn{2}{|c|}{$618.68(35)^{* * * *}$} & \multicolumn{2}{|c|}{$486.07(35)^{* * * * *}$} \\
\hline Log likelihood & \multicolumn{2}{|c|}{$-4,199.92$} & \multicolumn{2}{|l|}{$-4,192.16$} & \multicolumn{2}{|c|}{$-3,066.05$} \\
\hline
\end{tabular}

These are multilevel (random-intercept) logistic regression estimates obtained using the Stata's xtlogit command; numbers in italics indicate odd ratios; standard errors are listed in parentheses. Those who arrived in their host country 6 to 10 years ago is the reference category for other periods of arrival, and secular individuals serve as the reference category for religious groups. ESS = European Social Survey. $*_{p}<.05 . * *_{p}<.01$. ***p $<.001$. 


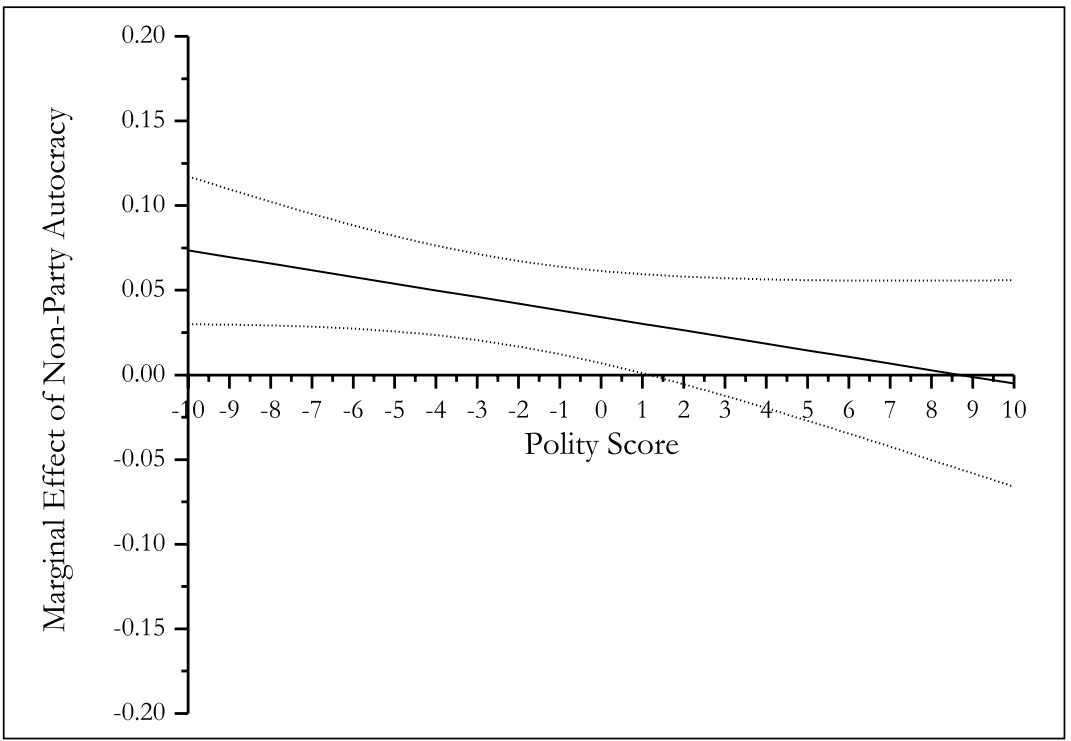

Figure 2. Marginal effects of nonparty autocracy and democracy level in origin country on partisanship acquisition among foreign-born immigrants in 19 Western democracies, 2002-2017.

only when polity score becomes positive - that is, at the value of 1 on the scale from -10 to +10 . What is more, the marginal effect of being from a nonparty autocracy is reduced by half (.074 vs. .034) when we compare the most authoritarian political regimes (with a polity score -10 ) and the least authoritarian systems within the range that is statistically distinguishable from zero (that is, with a polity score of 0 ).

Figure 3 turns to how the marginal effect of communism on the probability of left-wing partisanship changes as we move from the most authoritarian to the most democratic score of political regimes. Because the number of observations in these estimations is reduced (recall that we are looking at partisans only), the $95 \%$ confidence intervals are somewhat wider in this figure than in the graph presenting the results with respect to partisanship acquisition. However, the patterns are clear: The negative effect of communism declines from -.089 to -.065 as we move from the most negative polity score $(-10)$ to +2 - the point at which the marginal effect of communism becomes statistically indistinguishable from zero. Taken together, the results confirm that political regimes in migrants' origin countries play a role in shaping newcomers' attachments to political parties in their new homeland. 


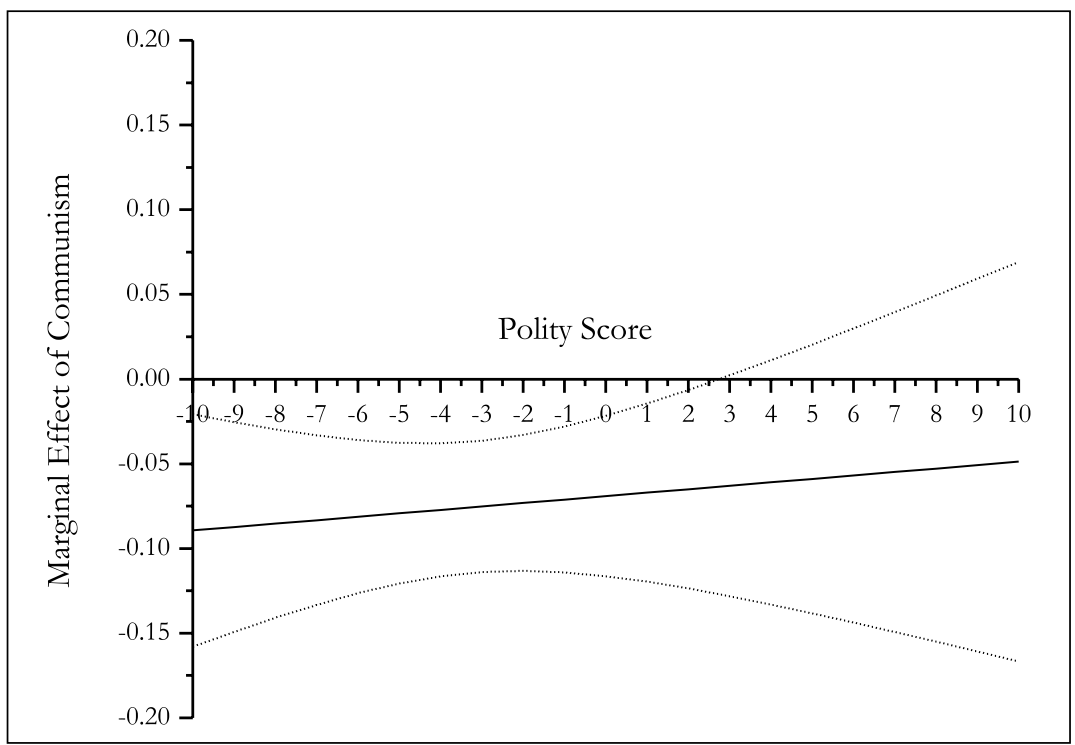

Figure 3. Marginal effects of communism and democracy level in origin country on left-wing partisanship among foreign-born partisans in 19 Western democracies, 2002-2017.

Specifically, authoritarianism levels in origin country magnify the impact of nonparty autocracy and communism on party identification: Foreign-born individuals from nonparty autocracies are particularly inclined to become partisans if they came from a highly authoritarian regime. Similarly, those with exposure to communist regimes in their origin country are especially unlikely to identify with left-wing parties if they arrived from a highly authoritarian regime.

To further test the robustness of my findings, I performed several additional analyses. First, because some of my controls-left-wing economic and social orientations - may not be independent from socialization experiences in migrant's origin country, I reestimated all models without these attitudinal variables. I found that the results with respect to my key variables of interest remained essentially unchanged. Furthermore, I was interested in whether accounting for one's refugee status had an impact on my findings. Because the ESS data do not include any survey items for this purpose, I have created an additional indicator capturing the intensity of military conflict in migrant's origin country at the time of arrival to one's host country, as individuals fleeing conflict areas are more likely to be refugees. ${ }^{27} \mathrm{I}$ found that the variable had 
no statistically significant effect in any of my models, while the results with respect to my main variables of interest remained the same. In addition, I reran my models using a Heckman selection model using partisanship acquisition as a dependent variable in my selection equation and left-wing partisanship among partisans as a dependent variable in the outcome equation..$^{28}$ The results revealed no considerable change in the coefficients of my key variables, while the likelihood-ration test of independent equations suggested that there was no need for a selection model.

Finally, I have tested whether the effects of origin country characteristics interact with migrant's duration of stay in his or her host country but found no statistically significant results for the interaction terms. The results of my estimations therefore provide no evidence that the impact of being from a nonparty autocracy or a communist regime is either weaker or stronger when comparing more recent arrivals to foreign-born immigrants who have been in their host country for a long time. However, given the cross-sectional nature of the survey data employed in this study, one cannot adequately assess whether the effects of premigration political socialization indeed remain the same as individual immigrants spend more years in their host country. Future studies using panel data would certainly help in shedding more light on this issue.

\section{Conclusion}

Party loyalties are central to democratic politics. They motivate people to participate in politics, structure their political views and voting choices, and consequently enhance stability and continuity of electoral politics. Despite party dealignment taking place in many Western democracies, partisanship continues to exert a powerful impact on various aspects of people's political attitudes and behavior (Dalton, 2016). Because foreign-born individuals usually lack parental socialization into their host country's politics, they are often assumed to arrive without clear party preferences and develop them in response to their experiences in the new homeland. However, studies seeking to explain party loyalties among newcomers show that origin country has a powerful and persistent effect, and that this effect does not disappear even when controlling for a host of traditional explanations of party allegiances (Bird et al., 2011, Chapter 3; Lien et al., 2004, Chapter 4; Wong et al., 2011, p. 144; Teney et al., 2010; Wüst, 2000, 2004).

To better understand how and why origin country matters, this article examines the consequences of premigration experiences of political regimes for the patterns of party identification among first-generation immigrants in established democracies. By replacing proper names of immigrants' origin 
countries with substantive variables - in this case, the nature of political regimes - this broadly cross-national study is the first to systematically assess the effect that exposure to a nonparty autocracy has on partisanship acquisition in one's host country, and the extent to which experience of communism influences the ideological orientation of that partisanship.

The analyses clearly demonstrate that foreign-born individuals who arrived from nonparty autocracies are more likely to acquire partisanship in their new homeland than newcomers from party-based autocracies or democracies. These findings are in line with my expectation that, lacking opportunities to identify with political parties back at home, immigrants from nonparty autocracies are more likely to welcome an opportunity to do so in their host country. Furthermore, among partisans, I find that, compared with immigrants from noncommunist countries, arrivals from communist regimes are less likely to identify with a left-wing party in their host country as a reaction to the far-left ideological nature of their origin country's autocracy.

Taken together, the results confirm that the critical difference in explaining the patterns of party identification among foreign-born individuals is not between democracies and nondemocracies, as is usually assumed in existing research, but between nonparty autocracies and party-based regimes. However, this does not mean that authoritarianism/democracy levels in origin country are irrelevant. The results of this study show that authoritarianism level magnifies the effects of nonparty autocracies and communism on the patterns of partisanship among new arrivals: Foreign-born individuals from nonparty autocracies are more likely to become partisans if they came from a particularly authoritarian regime. Similarly, the negative effect of communism on left-wing partisanship is stronger among newcomers who were socialized in a strongly authoritarian system and weaker-if their origin country had a mild degree of authoritarianism.

Considering these findings, future research on immigrant political behavior would benefit from more attention given to the consequences of premigration political experiences among foreign-born individuals. While this study focused on the patterns of party identification, origin country political socialization may also directly shape newcomers' electoral behavior in their host country. For example, exposure to a communist regime may reduce not only the odds of identification with a left-wing party but also the choice of a leftwing party among nonpartisans at the time of elections. Furthermore, while this study emphasized the importance of socialization in a nonparty autocracy for partisanship acquisition, accounting for exposure to a military or personalist regime may prove to be relevant in explaining other aspects of newcomers' political attitudes and behavior, such as justification for the use of force in politics or preferences for a strong leader. 
Scholars may also want to consider how various aspects of premigration political socialization interact with newcomers' experiences of their host country's political environment. Early experiences in one's adopted homeland may be particularly important, as there is evidence that immigrants with exposure to high voter turnout in the first elections upon arrival are subsequently more likely to vote (White, 2017). It remains to be seen whether "formative" elections have a similar effect on immigrant party preferences. One could expect, for example, that where the first elections experienced by an immigrant in his or her host country resulted in an electoral defeat of leftwing parties, the negative effects of communism on left-wing partisanship among foreign-born individuals might be reinforced. In contrast, where a left-wing party enjoys high visibility in public office and remains electorally popular, the skeptical attitudes of arrivals from communist regimes toward left-wing parties may weaken considerably.

Existing research on immigrant party allegiances also suggests that besides party policies dealing with the treatment of ethnic minorities and immigrants in their host country (e.g., Bowler, Nicholson, \& Segura, 2006), party foreign policy stances matter as well (Cain et al., 1991; Girard et al., 2012; Lim, Barry-Goodman, \& Branham, 2006). However, no existing study has sought to directly measure party foreign-policy positions and systematically examine their consequences, alone or in interaction with newcomers' premigration experiences. The extent to which immigrants are indeed swayed by government ideological or policy positions, as opposed to merely reacting to impulses acquired though political socialization in their origin country, is a question that deserves further research. ${ }^{29}$

Finally, this study also offers important insights for electoral strategies of political parties. Ethnic minorities in Western democracies, including foreign-born immigrants, are usually assumed to be politically disengaged, or if they are engaged - to be a clear-cut constituency of left-wing parties. Some scholars even expressed concern that strong and stable preferences for leftwing parties among newcomers may result in reduced incentives for candidates and parties to compete for the immigrant vote (Bird et al., 2011, p. 271). As this study shows, premigration experiences of foreign-born individuals from nonparty autocracies, particularly if they originate from highly authoritarian regimes, are eager to join in the political process of their democratic host country by developing party attachments. Moreover, foreign-born individuals from communist regimes tend to gravitate to center-right parties. This means that where newcomers from these regimes constitute considerable shares of their host country's population or their local constituency, rightwing parties may enhance their electoral support (and reduce their anti-immigrant reputation) by simply engaging in more active mobilization of these immigrants. 


\section{Declaration of Conflicting Interests}

The author declared no potential conflicts of interest with respect to the research, authorship, and/or publication of this article.

\section{Funding}

The author received no financial support for the research, authorship, and/or publication of this article.

\section{Supplemental Material}

Supplemental material for this article is available online at the CPS website http:// journals.sagepub.com/doi/suppl/10.1177/0010414018797938

\section{Notes}

1. West European countries here refer to Austria, Belgium, Denmark, Finland, France, Germany, Greece, Iceland, Ireland, Italy, Luxembourg, the Netherlands, Norway, Portugal, Spain, Sweden, Switzerland, and the United Kingdom.

2. Detailed information for each country is available in the Online Appendix.

3. For example, in the run-up to Germany's 2005 general election, the country's most circulated daily, Bild, asked on its front page: "Will Turks Decide the Election?" There is also evidence that the Turkish electorate has prompted Germany's mainstream parties to devise strategies for capturing the "ethnic vote" (Dancygier \& Saunders, 2006, p. 963). Similar efforts of political parties to attract immigrant voters have been noted by scholars also in the United States (e.g., Ramakrishnan, 2005, p. 2).

4. Recent research on Cuban Americans suggests that support for the Republican Party is weaker among more recent Cuban immigrants than those who left the island shortly after the communist revolution in 1959 (e.g., Eckstein, 2009; Girard, Grenier, \& Gladwin, 2012). This is partly because more recent immigrants have lower socioeconomic status, but also because they have closer ties to people who remain on the island and therefore have stronger reasons to oppose the trade embargo and travel restrictions on their origin country (Bishin \& Klofstad, 2012).

5. Evidence of transferability in migrants' political attitudes and behavior has also been presented by Luttmer and Singhal (2011), Rice and Feldman (1997), and White, Nevitte, Blais, Gidengil, and Fournier (2008).

6. Patronage may be particularly effective in communist regimes that rely on command economy because the ruling party has a complete monopoly over all valuable resources in a country. However, the use of patronage to "trap" citizens into supporting the regime has been found also in noncommunist single-party autocracies. For example, Magaloni (2006) shows that, for many years, the Institutional Revolutionary Party (PRI) in Mexico relied on policies that prevented peasants from rising out of poverty, thereby ensuring their continued dependence on state patronage through the PRI. 
7. Engaging in ritualistic political activism was nonetheless rational for ordinary citizens because it enabled them to demonstrate allegiance to the political order and thereby ensure their continued access to the state-run patronage system.

8. For a full list of countries classified as party-based autocracies, nonparty autocracies, and communist regimes, please see the Online Appendix.

9. In some East Central European countries, public hostility to communism was further exacerbated by nationalist grievances (Darden \& Grzymala-Busse, 2006).

10. A surprising revival of communist successor parties in some East Central European countries after the collapse of communism in the 1990s has been attributed primarily to the ability of these parties to reinvent themselves in organizational and programmatic terms (Grzymala-Busse, 2002; Mahr \& Nagle, 1995). Specifically, where these parties were able to embrace pro-reform policies and transform themselves into social democratic parties - a process facilitated by party centralization designed to minimize internal resistance of party members to this programmatic turnaround - they were able to rebuild their public image, previously discredited by party's association with the communist regime. In addition, some of these parties have been able to introduce new issue dimensions (such as managerial experience) that further contributed to their electoral success. Hence, existing research emphasizes party agency rather than electoral demand in explaining a revival of ex-communist parties in postcommunist societies. This of course does not rule out a possibility that some small group of voters may cast their ballots for these parties because of their communist convictions, and there is some evidence that ideology indeed plays a role in understanding electoral support for the PDS in East Germany (Doerschler \& Banaszak, 2007). However, these findings should not have significant consequences for my study for several reasons. First, there is evidence that communist regimes were widely disliked by the public (Kuran, 1991, p. 32), suggesting that true supporters of communism could not have been more than a marginal group. Moreover, considering that individuals self-select into migration, those who chose to relocate to Western democracies are unlikely to include individuals who prefer communist regimes.

11. The analyses of my study are based on respondents at least 18 years old at the time of the survey. However, including respondents who are below the legal age for political participation in most countries has no impact on my results.

12. Among foreign-born individuals who have citizenship of their host country, $52 \%$ reported feeling close to a party in their host country.

13. Where there was no information on party positions (for example, in case of non-EU countries or particularly small parties), I used European Social Survey (ESS) party descriptions in Appendix A3 available for each survey round on the ESS website (http://www.europeansocialsurvey.org/data/) to determine whether they were left-wing or not. Almost all parties with a left-right score of less than five were classified as socialist, radical left, green, or regional parties in the Chapel Hill data. The few exceptions were several liberal partiesDemocrats 66 in the Netherlands, Liberal Democrats in the United Kingdom, and the Liberal Forum (LIF) in Austria - and the Humanist Democratic Center 
(CHD) in Belgium, considered Christian democratic. Because neither liberals nor Christian democrats are traditionally seen as left-wing party families, I did not include these parties into the category of left-wing parties in my analyses. However, classifying them as left-wing does not change my findings in any appreciable way and my inferences remain the same (the results are available from the author upon request).

14. Note that in the category of nonparty autocracies I also include Iran (since 1980) - a rare case of theocracy, or religious autocracy. Excluding Iran from the sample, however, does not influence my results in any way.

15. Geddes (1999, pp. 124-125) defines party-based autocracies (or single-party autocracies) as civilian autocracies, where "a party organization exercises some power over the leader at least part of the time, controls the career paths of officials, organizes the distribution of benefits to supporters, and mobilizes citizens to vote and show support for party leaders in other ways." Where the line between democratic and autocratic regimes is ambiguous, a country is considered a party autocracy if parties other than the ruling party have been banned or subjected to serious harassment or institutional disadvantage, or if the dominant party has never lost control of the executive since coming to power and usually wins more than two thirds of the seats in the legislature.

16. Large numbers of arrivals from party-based autocracies in Portugal are due to immigrants from Angola - a former Portuguese colony that has been a party autocracy since its independence in 1975.

17. Disaggregating nonparty and party-based autocracies into Geddes, Wright, and Frantz (2014) original categories reveals that pure-type party autocracy (or single-party autocracy) is the second most common type of political regime (after democracy) in origin country of foreign-born individuals in Western Europe: $44 \%$ of arrivals from autocracies came from countries that were party autocracies at the time of arrival, while those who came from personalist, military regimes, monarchies, and mixed autocracies add up to $20 \%, 3 \%, 10 \%$, and $20 \%$, respectively (this figure is available in the Online Appendix).

18. An alternative measure for my analysis would be an indicator of government ideology that locates all autocracies along the left-right continuum. However, such indicator is not available for autocracies, particularly where measurements of a wide range of countries and over time are required, as is the case in this study.

19. For a full list of countries classified as party-based autocracies, nonparty autocracies, and communist regimes, please see the Online Appendix.

20. While social conservatism associated with religion contributes positively to identification with right-wing parties, churches or mosques linked to ethnic or racial minorities often help to mobilize people in support of left-wing parties that are usually more committed to promoting minority interests.

21. Unfortunately, the ESS does not allow us to clearly differentiate between perceptions of sociotropic discrimination and experiences of individual (egocentric) discrimination - a distinction found to be important in explaining left-wing party support in previous research (Sanders, Heath, Fisher, \& Sobolewska, 2014). 
22. Dropping a control for democracy in origin country so that the reference category for nonparty autocracies becomes all other political regimes (not shown) also produces a positive and highly statistically significant coefficient for nonparty autocracies.

23. Excluding foreign-born individuals from mixed autocracies from the sample produces identical results (these results are available in the Online Appendix).

24. Because the first four rounds of the ESS data coded recency of immigrant arrival as a categorical measure that captures only approximate number of years in host country, I used the following rule to identify individuals who migrated at the age of 18 or later: With respect to foreign-born respondents who arrived more than 20 years ago, I kept only those respondents who were at least 48 years old at the time of the survey; arrivals between 11 and 20 years ago had to be at least 38 years old, arrivals between 6 and 10 years ago - at least 23 years old, and those who came within the last year - at least 19 years old at the time of the survey.

25. Note that including nonpartisans in these analyses makes the results even stronger.

26. Using polity scores instead of the dummy variable for democracies also results in a statistically insignificant coefficient.

27. The conflict intensity measure was taken from the UCDP/PRIO Armed Conflict Dataset Version 4-2016, 1945-2015 (Gleditsch, Wallensteen, Eriksson, Sollenberg, \& Strand, 2002; Melander, Petterson, \& Themnér, 2016).

28. Since I employ dichotomous dependent variables in both selection and outcome equations, I used a censored probit model, estimated with the Stata command "heckprob."

29. Another possibility is that foreign-born individuals reward political parties that were in power in their host country at the time of their arrival because they may see these parties - regardless of their ideological orientation - as enablers of their migration. This possibility is not explored in my article because the survey data I rely on include only an approximate measure of migrants' duration of stay in their host country, which precludes identification of the ideological orientation of host country's government at the time of arrival.

\section{References}

Aldrich, J. H. (1995). Why parties? The origin and transformation of political parties in America. Chicago, IL: University of Chicago Press.

Almond, G. A., \& Verba, S. (1963). The civic culture. Boston, MA: Little, Brown.

Alvarez, M. R., \& Bedolla, L. G. (2003). The foundations of Latino voter partisanship: Evidence from the 2000 election. The Journal of Politics, 65, 31-49.

Bakker, R., Edwards, E., Hooghe, L., Jolly, S., Koedam, J., Kostelka, F., \& Zilovic, M. (2015). 1999-2014 Chapel Hill expert survey trend file (Version 1.13). Chapel Hill: University of North Carolina.

Bateson, R. (2012). Crime victimization and political participation. American Political Science Review, 106, 570-587. 
Bergh, J., \& Bjørklund, T. (2011). The revival of group voting: Explaining the voting preferences of immigrants in Norway. Political Studies, 59, 308-327.

Bilodeau, A. (2008). Immigrants' voice through protest politics in Canada and Australia: Assessing the impact of pre-migration political repression. Journal of Ethnic and Migration Studies, 34, 975-1002.

Bilodeau, A. (2014). Is democracy the only game in town? Tension between immigrants' democratic desires and authoritarian imprints. Democratization, 21, 359-381.

Bilodeau, A., McAllister, I., \& Kanji, M. (2010). Adaptation to democracy among immigrants in Australia. International Political Science Review, 31, 141-166.

Bird, K., Saalfeld, T., \& Wüst, A. M. (Eds.). (2011). The political representation of immigrants and minorities. London, England: Routledge.

Bishin, B. G., \& Klofstad, C. A. (2012). The political incorporation of Cuban Americans: Why won't Little Havana turn blue? Political Research Quarterly, 65, 586-599.

Blais, A., Gidengil, E., Nadeau, R., \& Nevitte, N. (2001). Measuring party identification: Britain, Canada, and the United States. Political Behavior, 23, 5-22.

Bowler, S., Nicholson, S. P., \& Segura, G. M. (2006). Earthquakes and aftershocks: Race, democracy, and partisan change. American Journal of Political Science, 50, 146-159.

Brooker, P. (2009). Non-democratic regimes (2nd ed.). New York, NY: Palgrave Macmillan.

Brownlee, J. (2007). Authoritarianism in an age of democratization. New York, NY: Cambridge University Press.

Budge, I., Crewe, I., \& Farlie, D. J. (Eds.). (1976). Party identification and beyond. New York, NY: John Wiley.

Cain, B. E., Kiewiet, D. R., \& Uhlaner, C. J. (1991). The acquisition of partisanship by Latinos and Asian Americans. American Journal of Political Science, 35, 390-422.

Calhoun-Brown, A. (1996). African American churches and political mobilization: The psychological impact of organizational resources. Journal of Politics, 58, 935-953.

Campbell, A., Converse, P. E., Miller, W. E., \& Stokes, D. E. (1960). The American voter. New York, NY: Willey.

Campbell, A., Converse, P. E., Miller, W. E., \& Stokes, D. E. (1966). Elections and the political order. New York, NY: Wiley.

Cheibub, J. A., Gandhi, J., \& Vreeland, J. R. (2010). Democracy and dictatorship revisited. Public Choice, 143, 67-101.

Chong, D., \& Kim, D. (2006). The experiences and effects of economic status among racial and ethnic minorities. American Political Science Review, 100, 335-351.

Czaika, M., \& de Haas, H. (2015). The globalization of migration: Has the world become more migratory? International Migration Review, 48, 283-323.

Dalton, R. J. (2016). Party identification and its implications. In W. R. Thompson (Ed.), Oxford research encyclopedia of politics. Oxford, UK: Oxford University Press, pp. 1-18. 
Dancygier, R., \& Saunders, E. N. (2006). A new electorate? Comparing preferences and partisanship between immigrants and natives. American Journal of Political Science, 50, 962-981.

Darden, K., \& Grzymala-Busse, A. (2006). The great divide: Literacy, nationalism, and the communist collapse. World Politics, 59, 83-115.

Davenport, C. (2007). State repression and the tyrannical peace. Journal of Peace Research, 44, 485-504.

De la Garza, R. O., DeSipio, L., Garcia, F. C., Garcia, J., \& Falcon, A. (1992). Latino voices: Mexican, Puerto Rican, and Cuban perspectives on American politics. Boulder, CO: Westview Press.

DiFranceisco, W., \& Gitelman, Z. (1984). Soviet political culture and "covert participation" in policy implementation. American Political Science Review, 78, 603621.

Dimitrov, M. K. (Ed.). (2013). Why communism did not collapse: Understanding authoritarian regime resilience in Asia and Europe. New York, NY: Cambridge University Press.

Doerschler, P., \& Banaszak, L. A. (2007). Voter support for the German PDS over time: Dissatisfaction, ideology, losers and east identity. Electoral Studies, 26, 359-370.

Eckstein, S. E. (2009). The immigrant divide: How Cuban Americans changed the US and their homeland. New York, NY: Routledge.

Eurostat. (2018.). Data on asylum and managed migration. Retrieved from http:// ec.europa.eu/eurostat/data/database

Festinger, L. (1957). A theory of cognitive dissonance. Stanford, CA: Stanford University Press.

Finifter, A. W., \& Finifter, B. M. (1989). Party identification and political adaptation of American migrants in Australia. The Journal of Politics, 51, 599-630.

Fiorina, M. P. (1981). Retrospective voting in American national elections. New Haven, CT: Yale University Press.

Franklin, C. H., \& Jackson, J. E. (1983). The dynamics of party identification. American Political Science Review, 77, 957-973.

Geddes, B. (1995). A comparative perspective on the Leninist legacy in Eastern Europe. Comparative Political Studies, 28, 239-274.

Geddes, B. (1999). What do we know about democratization after twenty years? Annual Review of Political Science, 2, 115-144.

Geddes, B., Wright, J., \& Frantz, E. (2014). Autocratic breakdown and regime transitions. Perspectives on Politics, 12, 313-331.

Girard, C., Grenier, G. J., \& Gladwin, H. (2012). Exile politics and Republican Party affiliation: The case of Cuban Americans in Miami. Social Science Quarterly, 93, 42-57.

Gleditsch, N. P., Wallensteen, P., Eriksson, M., Sollenberg, M., \& Strand, H. (2002). Armed conflict 1946-2001: A new dataset. Journal of Peace Research, 39, 615637.

Gold, S. J. (1986). Styles of activism within refugee communities: The case of Soviet Jews and Vietnamese. Kroeber Anthropological Society Papers, 65-66, 35-45. 
Grzymala-Busse, A. (2002). The programmatic turnaround of communist successor parties in East Central Europe, 1989-1998. Communist and Post-Communist Studies, 35, 51-66.

Hadenius, A., \& Teorell, J. (2007). Pathways from authoritarianism. Journal of Democracy, 18, 143-157.

Hajnal, Z., \& Lee, T. (2006). Out of line: Immigration and party identification among Latinos and Asian Americans. In T. Lee, S. K. Ramakrishnan, \& R. Ramirez (Eds.), Transforming politics, transforming America: The political and civic incorporation of immigrants in the United States (pp. 129-150). Charlottesville: University of Virginia Press.

Hajnal, Z. L., \& Lee, T. (2011). Why Americans don't join the party: Race, immigration, and the failure (of political parties) to engage the electorate. Princeton, NJ: Princeton University Press.

Hansen, S. B. (1997). Talking about politics: Gender and contextual effects on political proselytizing. Journal of Politics, 59, 73-103.

Heath, A. F., Fisher, S. D., Sanders, D., \& Sobolewska, M. (2011). Ethnic heterogeneity in the social bases of voting at the 2010 British general election. Journal of Elections, Public Opinion and Parties, 21, 255-277.

Holmberg, S. (1994). Party identification compared across the Atlantic. In M. K. Jennings \& T. E. Mann (Eds.), Elections at home and abroad: Essays in honor of Warren E. Miller (pp. 93-121). Ann Arbor: University of Michigan Press.

Holmes, L. (1997). Post-communism: An introduction. Cambridge, MA: Polity Press.

Huntington, S. P., \& Moore, C. H. (1970). Authoritarian politics in modern society: The dynamics of established one-party systems. New York, NY: Basic Books.

Jaggers, K., \& Gurr, T. R. (1995). Tracking democracy's third wave with the Polity III data. Journal of Peace Research, 32, 469-482.

Jennings, M. K. (1983). Gender roles and inequalities in political participation: Results from an eight-nation study. Western Political Quarterly, 36, 364-385.

Jennings, M. K., \& van Deth, J. W. (with Barnes, S. H., Fuchs, D., Heunks, F. J., Inglehart, R., Kaase, M., Klingemann, H.-D., \& Thomassen, J. J. A.). (1989). Continuities in political action: A longitudinal study of political orientations in three Western democracies. New York, NY: De Gruyter.

Just, A. (2017). The far-right, immigrants, and the prospects of democracy satisfaction in Europe. Party Politics, 23, 507-525.

Just, A., \& Anderson, C. J. (2012). Immigrants, citizenship and political action in Europe. British Journal of Political Science, 42, 481-509.

Just, A., \& Anderson, C. J. (2014). Opinion climates and immigrant political action. Comparative Political Studies, 47, 935-965.

Kittilson, M. C. (2009). Research resources in comparative political behavior. In R. J. Dalton \& H.-D. Klingemann (Eds.), The Oxford handbook of political behavior (pp. 865-895). Oxford, UK: Oxford University Press.

Kuran, T. (1991). Now or never: The element of surprise in the East European Revolution of 1989. World Politics, 44, 7-48. 
Lai, B., \& Slater, D. (2006). Institutions of the offensive: Domestic source of dispute initiation in authoritarian regimes, 1950-1992. American Journal of Political Science, 50, 113-126.

Lien, P.-T., Conway, M. M., \& Wong, J. (2004). The politics of Asian Americans: Diversity and community. New York, NY: Routledge.

Lim, P. S., Barry-Goodman, C., \& Branham, D. (2006). Discrimination that travels: How ethnicity affects party identification for Southeast Asian immigrants. Social Science Quarterly, 87, 1158-1170.

Lupia, A. (1994). Shortcuts versus encyclopedias: Information and voting behavior in California insurance reform elections. American Political Science Review, 88, 63-73.

Luttmer, E. F. P., \& Singhal, M. (2011). Culture, context, and the taste for redistribution. American Economic Journal: Economic Policy, 3, 157-179.

Magaloni, B. (2006). Voting for autocracy: The politics of party hegemony and Its demise. Cambridge, UK: Cambridge University Press.

Magaloni, B., \& Kricheli, R. (2010). Political order and one-party rule. Annual Review of Political Science, 13, 123-143.

Mahr, A., \& Nagle, J. (1995). Resurrection of the successor parties and democratization in East-Central Europe. Communist and Post-Communist Studies, 28, 393-409.

Marshall, M. G., Gurr, T. R., \& Jaggers, K. (2017). Polity IV project: Political regime characteristics and transitions, 1800-2016. Dataset Users' Manual. Center for Systemic Peace. Retrieved from http://www.systemicpeace.org/inscr/p4manualv2016.pdf

McAllister, I., \& Makkai, T. (1991). The formation and development of party loyalties: Patterns among Australian immigrants. Australian and New Zealand Journal of Sociology, 27, 195-217.

McAllister, I., \& Makkai, T. (1992). Resource and social learning theories of political participation: Ethnic patterns in Australia. Canadian Journal of Political Science, 25, 269-293.

Melander, E., Petterson, T., \& Themnér, L. (2016). Organized violence, 1989-2015. Journal of Peace Research, 53, 727-742.

Money, J. (1997). No vacancy: The political geography of immigration control in advanced industrial countries. International Organization, 51, 685-720.

Ndukwe, T. C. (2015). The role of the church and mosque in the political mobilization of Black African immigrants in Finland at the municipal level. Politics, Religion \& Ideology, 16, 391-410.

Niemi, R. G., Powell, G. B., Jr., Stanley, H. W., \& Evans, C. L. (1985). Testing the converse partisanship model with new electorates. Comparative Political Studies, 18, 300-322.

Peceny, M., Beer, C., \& Sanchez-Terry, S. (2002). Dictatorial peace? American Political Science Review, 96, 15-26.

Popkin, S. L. (1991). The reasoning voter: Communication and persuasion in presidential campaigns. Chicago, IL: University of Chicago Press. 
Ramakrishnan, S. K. (2005). Democracy in immigrant America: Changing demographics and political participation. Stanford, CA: Stanford University Press.

Rice, T. W., \& Feldman, J. L. (1997). Civic culture and democracy from Europe to America. The Journal of Politics, 59, 1143-1172.

Rose, R., \& Haerpfer, C. (1993). Adapting to transformation in Eastern Europe: New democracies barometer II (Studies in Public Policy No. 212). Glasgow, Scotland: University of Strathclyde.

Rose, R., Mishler, W., \& Haerpfer, C. (1998). Democracy and its alternatives: Understanding post-communist societies. Baltimore, MD: Johns Hopkins University Press.

Sanders, D., Burton, J., \& Kneeshaw, J. (2002). Identifying the true party identifiers: A question wording experiment. Party Politics, 8, 193-205.

Sanders, D., Heath, A., Fisher, S., \& Sobolewska, M. (2014). The calculus of ethnic minority voting in Britain. Political Studies, 62, 230-251.

Sears, D. O., \& Levy, S. (2003). Childhood and adult political development. In D. O. Sears, L. Huddy, \& R. Jervis (Eds.), Oxford handbook of political psychology (pp. 60-109). New York, NY: Oxford University Press.

Snijders, T. A. B., \& Bosker, R. J. (1999). Multilevel analysis: An introduction to basic and advanced multilevel modeling. Thousand Oaks, CA: Sage.

Sobolewska, M. (2005). Ethnic agenda: Relevance of political attitudes to party choice. Journal of Elections, Public Opinion and Parties, 15, 197-214.

Steenbergen, M. R., \& Jones, B. S. (2002). Modeling multilevel data structures. American Journal of Political Science, 46, 218-237.

Strijbis, O. (2014). Migration background and voting behavior in Switzerland: A socio-psychological explanation. Swiss Political Science Review, 20, 612-631.

Svolik, M. (2008). Authoritarian reversals and democratic consolidation. American Political Science Review, 102, 153-168.

Takaki, R. (1989). Strangers from a different shore. Boston, MA: Little, Brown.

Teney, C., Jacobs, D., Rea, A., \& Delwit, P. (2010). Ethnic voting in Brussels: Voting patterns among ethnic minorities in Brussels (Belgium) during the 2006 local elections. Acta Politica, 45, 273-297.

Uhlaner, C. J. (1991). Perceived discrimination and prejudice and the coalition prospects of Blacks, Latinos and Asian Americans. In B. O. Jackson \& M. B. Preston (Eds.), Racial and ethnic politics in California (pp. 339-371). Berkeley: University of California, Institute of Governmental Studies Press.

Uhlaner, C. J., \& Garcia, F. C. (2002). Latino public opinion. In B. Norrander \& C. Wilcox (Eds.), Understanding public opinion (pp. 77-101). Washington, DC: CQ Press.

Unger, A. (1981). Political participation in the USSR: YCL and CPSU. Soviet Studies, $33,107-124$.

Verba, S., \& Nie, N. H. (1972). Participation in America. New York, NY: Harper and Row.

Verba, S., Nie, N. H., \& Kim, J. (1971). The modes of democratic participation: $A$ cross-national comparison. Beverly Hills, CA: Sage. 
Verba, S., Schlozman, K. L., Brady, H., \& Nie, N. H. (1993). Race, ethnicity and political resources: Participation in the United States. British Journal of Political Science, 23, 453-497.

Verba, S., Schlozman, K. L., \& Brady, H. E. (1995). Voice and equality: Civic voluntarism in American politics. Cambridge, MA: Harvard University Press.

Walder, A. G. (1994). The decline of communist power: Elements of a theory of institutional change. Theory and Society, 23, 297-323.

White, S. (2017). Canadian immigrants at the polls: The effects of socialization in the country of origin and resocialization in Canada on electoral participation. Political Science, 69, 101-121.

White, S., Nevitte, N., Blais, A., Gidengil, E., \& Fournier, P. (2008). The political resocialization of immigrants: Resistance of lifelong learning? Political Research Quarterly, 61, 268-281.

Wolfinger, R. E., \& Rosenstone, S. J. (1980). Who votes? New Haven, CT: Yale University Press.

Wong, J. S. (2000). The effects of age and political exposure on the development of party identification among Asian American and Latino immigrants in the United States. Political Behavior, 22, 341-371.

Wong, J S., Ramakrishnan, S. K., Lee, T., \& Junn, J. (2011). Asian American political participation: Emerging constituents and their political identities. New York, NY: Russell Sage Foundation.

Wright, J. (2008). Do authoritarian institutions constrain? How legislatures affect economic growth and investment. American Journal of Political Science, 52, 322-343.

Wüst, A. M. (2000). New citizens-new voters? Political preferences and voting intentions of naturalized Germans: A case study in progress. The International Migration Review, 34, 560-567.

Wüst, A. M. (2004). Naturalized citizens as voters: Behavior and impact. German Politics, 13, 341-359.

Zaller, J. R. (1992). The nature and origins of mass opinion. Cambridge, UK: Cambridge University Press.

Zingher, J. N., \& Thomas, M. S. (2012). Patterns of immigrant political behavior in Australia: An analysis of immigrant voting in ethnic context. Australian Journal of Political Science, 47, 377-397.

\section{Author Biography}

Aida Just is an Associate Professor of Political Science and Public Administration at Bilkent University in Turkey. Her research focuses on comparative political behavior and public opinion, especially with respect to the issues of democratic legitimacy, representation, and mass political engagement. 